\title{
Mariana Colomer, Libro de la suavidad, Madrid, Huerga y Fierro, 2008, 87 pp.
}

La salida del tercero de los libros poéticos de Ana María Roig, que los firma con el nombre artístico de Mariana Colomer, ha supuesto para quien escribe estas notas una reafirmación en sus convicciones acerca de su valía literaria, una reafirmación que se sitúa en un momento de lectura que sucede a los precedentes de aprecio de sus valores: el de afirmación de los mismos tras leer Crónicas de altanería (1999), y el de su confirmación tras haber leído La gracia y el deseo (2003), libro que, al acoger entre sus cubiertas el conjunto inicial, pero revisado, ya alertaba sobre su escasa autoindulgencia respecto a su escritura más temprana.

Al no contemporizar consigo misma ni suscribir en su totalidad lo compuesto en su entrega inaugural, la autora barcelonesa puso sobreaviso a sus lectores que había optado por una severa autoexigencia, ostensibilizada palmariamente en su Libro de la suavidad (2008). Esta nueva obra, a la vez que consolida su universo propio, lo enriquece aún más. Y es que, en efecto, si su mundo literario se distingue por el ansia de belleza espiritual, manifiesta a través de la dimensión eróticoreligiosa, así como de su voz lírica, Libro de la suavidad aporta más indagación mistérica, y más depuración estética, a sus claves distintivas, como vamos a comentar a continuación.

La vertiente erótica que caracteriza a esta poeta desde los inicios de su trayectoria se asienta en sublimar su cotidianidad sin nunca perder de vista el horizonte de una visión sobrenatural de la vida humana. Tal visión trascendente figura implícita en el título de su libro más temprano, Crónicas de altanería, porque no debe olvidarse que Dámaso Alonso, en un bien conocido artículo sobre San Juan de la Cruz, ya se refirió a la caza religiosa de amor como "de altanería”. Ese enfoque fue progresando y desarrollándose en su lírica, pero en vez de orientarse hacia un norte contemplativo, eligió subsumir la contemplación en el seno de la praxis activa.

La finalidad de ver la cara de Dios constituye una perspectiva de culminación del existir que responde a la ortodoxia cristiana más indubitable. Con todo, los tipos 
de vías orientadas al logro de ese fin pueden ser numerosísimas, siendo una de ellas la de la entrega solidaria, la cual estriba en no apartarse de la cotidianidad, de una cotidianidad que no peralta el ámbito doméstico, sino el compromiso social, un compromiso social radicado en el rasante más bajo del desvalimiento. Seguimos sin movernos del orbe sanjuanista, aunque alimentado por el prisma franciscano. El carmelita, en su poema "Tras de un amoroso lance", atestiguaba el "abatime tanto, tanto/ que fui tan alto, tan alto." Por su parte, San Francisco enseñó a leer la cara de Dios a través de la faz de las criaturas más desfavorecidas socialmente. Y ambas ópticas se entrecruzan en textos del Libro de la suavidad como "Amor, en la figura del pobre entre los pobres...", al que pertenecen los siguientes versos:

Amor, en la figura del pobre entre los pobres,

resplandecía allí en un pasillo

de las urgencias de un gran hospital.

Con qué suave demora acaricié

tus pies tan lacerados,

y derroché en lo oculto besos, lágrimas.

Con qué dulzura me abajabas

hasta hacerme sentir tan delicioso

el hedor de tus ropas,

y, así, a lo más alto llevarme.

y calzarme tus llagas y vestirte,

y no hallar más vocación que el amor.

y ser por Ti despreciada de todos.

Esta senda de compromiso extremo desprende un erotismo de índole espiritual tan bello como sublime, y entonces el lenguaje poético no cabe orientarlo hacia otra dirección que no sea la de la belleza expresiva, sintonizando y armonizándose de este modo en la hablante, su conducta como persona y su decir lírico, en el que se engastan continuos hallazgos lingüísticos, conceptuales y, de vez 
en vez, tropológicos, como lo ejemplifica el empleo del término "suavidad". Sustantivo muy empleado en la literatura ascético-mística del Siglo de Oro, y sugerente donde los haya, en ocasiones convoca alumbramientos teológicos como los que se atisban en la composición "Si en ti me contemplaste...": "Si en Ti me contemplaste, / si en soledad cercana fuiste herido, / si ahora, Tú en mi cuerpo, celebrado."

Entre las numerosas prácticas poéticas del fin del siglo pasado, y de comienzos del presente, en su poética ha acudido Mariana Colomer a la opción literaria de plasmar una lírica de acento religioso, y aun franciscano, que parecía casi inviable hoy, pero a la que su voz y su sentimiento han encauzado, posibilitando que su palabra, embebida en la añeja tradición áurea, nos transmita una elección estética de inusitada actualidad.

José María Balcells 